\title{
Long-Term Impact of Cattle Grazing on Subalpine Forest Development and Efficiency of Snow Avalanche Protection
}

\author{
Andrea C. Mayer*† and \\ Veronika Stöckli* \\ *WSL, Swiss Federal Institute for \\ Snow and Avalanche Research SLF, \\ Flüelastrasse 11, CH-7260 Davos Dorf, \\ Switzerland \\ †mayer@slf.ch
}

\begin{abstract}
The study presented herein investigated the differences in stand structure of grazed and ungrazed subalpine forests and whether subalpine forests used for grazing satisfactorily protect against avalanches. In subalpine forests of Picea abies L. Karst and Larix decidua Miller, grazed and ungrazed plots of $225 \mathrm{~m}^{2}$ were analyzed through the use of dendroecological methods. The grazed forests were found to be less dense than the ungrazed forests and to have a higher percentage of European larch. However, the density of the forests investigated was high enough to impede the release of avalanches. The young trees grew faster in the grazed forests. There were less dominant trees in grazed forests, and these trees were much older than in ungrazed forests. The main structure types in the grazed and ungrazed forests were multilayered open and uniform dense, respectively. The management of mountain forests as wood pastures seems to enhance the readiness of the forest owners to conduct selective logging operations. Thus, forest grazing can encourage the development of heterogeneously structured forest stands, which can regenerate more easily while fulfilling a function of avalanche protection.
\end{abstract}

\section{Introduction}

Mountain forests in the Alps traditionally fulfil several different benefits at the same time, such as wood production, protection against natural hazards, leisure, and biodiversity. Although generally multifunctionality of the forests is claimed, e.g., by the Swiss forest policy (Bundesamt für Umwelt, Wald und Landschaft, 1999), coexistence of certain forest uses is sometimes rejected. An example of debated coexistence of mountain forest functions is wood pasture combined with avalanche protection (Pollanschütz, 1995); mixing of these two uses has led to a long history of argumentation between foresters and agronomists in Switzerland (e.g., Fankhauser, 1870). Whereas the forest structure of wood pastures should offer enough open patches to ensure growth of ground vegetation (Domes, 1947), an avalancheprotection forest should have a high-density structure to ensure stabilization of the snow cover on the ground (Salm, 1978). This paper addresses whether both uses satisfactorily fulfil the needs in practice.

Cattle grazing is a traditional use of the forest and is still practiced in $15 \%$ of the mountain forests of Switzerland (Brassel and Brändli, 1999). Wood pastures optimally offer fodder and shelter for the animals against climate extremes such as snowfall, heat, or frost (McArthur, 1991). The wood pastures are mainly used in spring before grazing the alpine areas above treeline and in fall after grazing those areas (Mayer, 2003). An ideal forest used for grazing exhibits an open structure to provide a sufficient amount and quality of herbage for grazing cattle. Okland et al. (2003) emphasized that forest structure has much influence on understory vegetation. According to Domes (1952) the crown projection area of the forest stand should not exceed $80 \%$, and the herbage production increases with decreasing forest density. Documented principles of wood-pasture structure are nonexistent; hence forest utilization in terms of duration and area for grazing is based on the expertise of the local farmers. Subalpine forests mostly regenerate naturally (Brassel and Brändli, 1999). Intensive cattle grazing in the forest affects the regeneration of trees because of browsing and trampling (Mayer et al., 2005a). Although browsing of young trees increases with increasing levels of cattle stocking (Mayer et al., 2005b), the germination rate of subalpine conifers may be enhanced by intensive grazing (Mayer et al., 2005a). Hence, grazing intensity above a certain threshold can affect forest dynamics and structure.

Snow avalanches generally release on slopes between $30^{\circ}$ and $50^{\circ}$ (Salm et al., 1987). In a forest, interception of snow by tree crowns reduces the depth of the snow cover (Imbeck, 1983) and forces the development of an irregular and therefore more stable snowpack structure (In der Gand, 1978). Additionally, the trees stabilize the snow cover (Salm, 1978). The protective efficiency of forests is largely dependent on a sufficient number of trees per unit area, on the absence of larger forest openings, on an age structure ensuring the constant presence of larger trees, and on a species composition in which evergreen trees dominate (Ott, 1996; Salm, 1978). The overstory of an evergreen avalanche-protection forest should contain 250-400 stems per hectare (Meyer-Grass, 1987). Trees of diameters smaller than 6-10 cm exhibit elastic stem bases (Johnson, 1987) and barely contribute to the stabilization of the snow cover. In forest openings larger than $30 \mathrm{~m}$ in the direction of the slope and $15 \mathrm{~m}$ in the horizontal direction, avalanches may release (Imbeck, 1983), as the snow cover is stabilized by mature trees only for a distance of 2-3 m around the trunks (In der Gand, 1978). The structure of a forest for optimum avalanche protection requires certain stand characteristics, such as stand density and size of openings, which might conflict with characteristics that are ideal for forest grazing.

The goal of this study was to test whether the forest structure of long-term grazed forests compromises their avalanche-protection efficiency. We address two main questions: (1) What is the difference in stand structure of grazed and ungrazed subalpine forest concerning species composition, tree age, and forest density? (2) Is the protective efficiency of grazed forest stands satisfactory?

\section{Material and Methods}

\section{STUDY AREA}

The study area is located in the Dischma Valley near Davos in the eastern Swiss Alps $\left(46^{\circ} 46^{\prime} \mathrm{N}, 9^{\circ} 53^{\prime} \mathrm{W}\right)$. The valley ranges in elevation 
from 1600 to $2100 \mathrm{~m}$ above sea level. The soil is of humus Podzol character (Krause and Peyer, 1986), derived from crystalline rocks (Bosshard, 1986). The climate has both continental and oceanic aspects, as the region is located in the borderland of the central and the northern part of the Alps. Compared to other Alpine regions, the annual precipitation is relatively low, reaching $\sim 1050 \mathrm{~mm}$ per year from summer rain and winter snowfall (Günter, 1986b). The maximum snow depth is $\sim 2 \mathrm{~m}$ (Schönenberger and Frey, 1988). The mean monthly temperature is $-7^{\circ} \mathrm{C}$ in the coldest month (January) and $+12^{\circ} \mathrm{C}$ in the warmest month (July). Avalanches are common natural hazards in the Dischma Valley (Brugger, 2003) and have created and maintained treeless vertical stripes through the forest belt.

The forests in the Dischma Valley are dominated by Picea abies L. Karst (Norway spruce) and Larix decidua Miller (European larch); less frequently found tree species are Pinus cembra (Swiss stone pine) and Sorbus aucuparia (rowan) (Bosshard, 1986). The forest is mainly owned by farmers and has been selectively logged since settlement started in the thirteenth century (Laely, 1984). In 1873, the cantonal forest law was renewed, and the utilization of wood pastures by goats was interdicted. Since then, the wood pastures have been used only for grazing cattle. However, the intensity of agricultural activities in the valley decreased considerably during the twentieth century. In the beginning of the twentieth century, 35\% of the forest area of Davos was grazed by cattle (Günter, 1986a). Today, 17\% of the forest area is used for grazing cattle, usually several weeks per year, before and after the cattle graze in alpine ranges above the current tree line (Günter, 1984).

\section{SAMPLE SITES}

In fall 2001 , thirty $225-\mathrm{m}^{2}$ plots were located on a south-facing slope of the Dischma Valley, ranging from an elevation of $\sim 1600$ to $1950 \mathrm{~m}$ a.s.l. By using a random-number table, 15 plots were randomly selected in forests that had been grazed each summer at least since 1930 , and another 15 plots were randomly selected in forests that had not been grazed since 1930. The initial demarcation of an area as grazed or ungrazed was derived from Wildi and Ewald (1987) and Bebi (1999), and this interpretation was checked against the actual grazing regime during sampling. Large avalanche tracks were excluded from the study.

\section{SAMPLING}

The forest structure was sketched for each plot. In each plot, the species, height, and diameter of all trees was recorded, and tree cores were taken from the trees larger than $8 \mathrm{~cm}$ in diameter. Most of the tree cores were taken at a height of $0-30 \mathrm{~cm}$. However, from trees that had a rotten center at a height of $0-30 \mathrm{~cm}$, we took another sample at $150 \mathrm{~cm}$ height. To approach tree ages at sampling heights of $150 \mathrm{~cm}$, the average age of 24 young spruces that had a height between 130 and $170 \mathrm{~cm}$ was measured by counting bud scars and shoot whirls. Consequently, $30 \mathrm{yr}$ were added to the tree age measured at $150 \mathrm{~cm}$ height, in order to estimate the age of 20 sample trees that had a rotten center. To estimate the age of young trees that had a diameter up to $8 \mathrm{~cm}$, bud-scale scars and the yearly shoot whirls were counted. Additionally, the height of all trees was assessed. The heights of the trees up to $3 \mathrm{~m}$ were measured by using a pocket rule, the heights of the trees taller than $3 \mathrm{~m}$ were assessed by using a hypsometer.

\section{SAMPLE PROCESSING AND STATISTICAL ANALYSES}

All tree cores were processed following standard dendroecological procedures (Stokes and Smiley, 1968). For determining tree age based on tree cores where the pith could not be intercepted, the following formula was used (Duncan, 1989):

$$
n=l(l / 8 h)+(h / 2) x^{-1},
$$

where $n$ is the number of missing years between the last fully visible tree ring and the pith, $x$ is the width of the last tree ring fully visible on the core; $h$ is the distance between the margin of the core and the beginning of the first fully visible tree ring, and $l$ is the distance between both intercept points of the first tree ring and the margin of the core.

In cases where the center was missing because of butt rot or large tree radius, we subtracted the actual length of the core from the radius, determined from the diameter measured. We counted the number of rings on the inner part of the actual core along a stretch of the same length as the one that was missing, and then we added this number of years to the age of the actual core, assuming more or less constant growth. In total, the age of 15 trees $(2.3 \%$ of the trees $\geq 3 \mathrm{~m}$ tall) was calculated by using this method. The age of 18 trees $(2.7 \%$ of the trees $\geq 3 \mathrm{~m}$ tall) was calculated by using the method of bud-scale counting.

The trees were divided into three height classes- $\mathrm{H} 1$ (up to $3 \mathrm{~m}$ ), $\mathrm{H} 2$ (>3 m to $25 \mathrm{~m}$ ), and $\mathrm{H} 3$ (>25 m) —as actual tree height determined in the field might not be exact enough to be used in the analyses. H1 contained the regenerating trees up to $3 \mathrm{~m}$; these were not yet tall enough to stabilize the snow cover sufficiently as they were shorter than the threshold of $150 \%$ of the maximum snow-cover depth given by Saeki and Matsuoka (1969) and as their diameter was mostly (except for 12 trees) below the critical elasticity threshold of $6 \mathrm{~cm}$ stem diameter given by Johnson (1987).

To compare stand structure of grazed and ungrazed forests in terms of number of trees, species composition, and tree height, Wilcoxon ranksum tests were processed in S-Plus (MathSoft Inc., 1999). To compare the age structure of grazed and ungrazed plots, analyses of variance (ANOVA) and multiple comparisons between all the plots were processed in S-Plus (MathSoft Inc., 1999). The differences between grazed and ungrazed plots (GU), differences among grazed plots (GG), and differences among ungrazed plots (UU) were calculated. Then, the percentage of differences of the possible combinations of plots in each category (GU, GG, and UU) was calculated.

The avalanche-protection efficiency of forest plots in grazed and ungrazed areas was analyzed by comparing the numbers of trees $>3 \mathrm{~m}$ tall per hectare. In each plot, spaces of $>3 \mathrm{~m}^{2}$ where no tree of a minimal height of $3 \mathrm{~m}$ was growing were defined as gaps, and their area was determined. Gap sizes in grazed-forest (GF) and ungrazed-forest (UF) plots were compared by using the Wilcoxon rank-sum test.

\section{Results}

\section{FOREST DENSITY, GAP SIZE, AND SPECIES COMPOSITION}

On all plots investigated ( 0.675 ha total), 1238 trees were found, which is equivalent to 1834 trees per hectare. In total, the grazed forest (GF) was less dense (1704 trees per hectare) than the ungrazed forest (UF; 1964 trees per hectare). However, when comparing the tree numbers per plot in GF and UF, this difference was not significant. Most of the plots had a sufficient number of trees in the overstory (250 stems per hectare) to provide an avalanche-protection function as recommended by Meyer-Grass (1987). On none of the ungrazed plots and on two grazed plots, the number of trees $\geq 3 \mathrm{~m}$ was below that threshold. In $\mathrm{H} 1(<3 \mathrm{~m})$, there were fewer trees in the GF than in the UF, but this difference was not significant when comparing the tree numbers per plot in GF and UF. In H3 $(>25 \mathrm{~m})$, however, the difference in tree numbers per plot in GF and UF was significant; there were more than twice as many trees in UF than in GF (Table 1).

In all height classes, Norway spruce (Picea abies (L.) Karst) was the dominant trees species $(91.4 \%$; Table 1$)$. The percentage of 
TABLE 1

Stem number per hectare and percentage of Picea abies and Larix decidua in grazed and ungrazed forests.

\begin{tabular}{|c|c|c|}
\hline & Grazed forest & Ungrazed forest \\
\hline \multicolumn{3}{|l|}{ All trees } \\
\hline number per hectare (all species) & 1704 & 1964 \\
\hline percentage of $P$. abies, $L$. decidua & $86.8 \%, 12.7 \%^{\mathrm{a}}$ & $95.5 \%, 2.7 \%^{\mathrm{b}}$ \\
\hline \multicolumn{3}{|l|}{ Trees $<3$ m (H1) } \\
\hline number per hectare (all species) & 821 & 892 \\
\hline percentage of $P$. abies, L. decidua & $91.4 \%, 8.3 \%^{\mathrm{a}}$ & $93.7 \%, 3.0 \%^{\mathrm{b}}$ \\
\hline \multicolumn{3}{|l|}{ Trees 3-25 m tall (H2) } \\
\hline number per hectare (all species) & 779 & 797 \\
\hline percentage of $P$. abies, $L$. decidua & $81.7 \%,{ }^{\mathrm{a}} 17.5 \%^{\mathrm{a}}$ & $97.4 \%,{ }^{\mathrm{b}} 1.9 \%^{\mathrm{b}}$ \\
\hline \multicolumn{3}{|l|}{ Trees $>25 \mathrm{~m}$ tall $(\mathrm{H} 3)$} \\
\hline number per hectare (all species) & $104^{\mathrm{a}}$ & $276^{\mathrm{b}}$ \\
\hline percentage of $P$. abies, $L$. decidua & $88.5 \%,{ }^{\mathrm{a}} 11.5 \%^{\mathrm{a}}$ & $95.7 \%,^{\mathrm{b}} 4.3 \%^{\mathrm{b}}$ \\
\hline \multicolumn{3}{|l|}{ Trees $\geq 3 \mathrm{~m}$ tall $(\mathrm{H} 2+\mathrm{H} 3)$} \\
\hline number per hectare (all species) & 883 & 1073 \\
\hline percentage of $P$. abies, $L$. decidua & $82.6 \%,{ }^{\mathrm{a}} 16.8 \%{ }^{\mathrm{a}}$ & $96.9 \%,{ }^{\mathrm{b}} 2.5 \%^{\mathrm{b}}$ \\
\hline
\end{tabular}

${ }^{\mathrm{a}-\mathrm{b}}$ Means of grazed and ungrazed plots with different lowercase superscripts differ at $P<0.05$.

European larch (Larix decidua Miller) was 7.4\%. Species composition differed between grazed (GF) and ungrazed forests (UF; Table 1). In total, there was a significantly higher percentage of larches in the GF than in the UF. This was most obvious in the height classes $\mathrm{H} 2$ and H3. In H1, however, the difference in percentage of larch was not significant. Few rowans (Sorbus aucuparia L.) $(0.9 \%)$ were found. The percentage of rowans did not differ significantly between GF and UF, but the $P$-value was below 0.1 . Within H1, no rowan was found in the $\mathrm{GF}$, whereas in the UF, seven young rowans were found. Within $\mathrm{H} 2$ (trees 3-25 $\mathrm{m}$ tall), no difference was found in the number of rowans in GF and UF stands, and there was no rowan in $\mathrm{H} 3(>25 \mathrm{~m})$ as the species does not grow higher than $15 \mathrm{~m}$ (Lauber and Wagner, 1996). Stone pines (Pinus cembra L.) were found in the lowest height class $\mathrm{H} 1(<3 \mathrm{~m})$ and in only a low percentage $(0.3 \%$ of all trees).

The gap size (areas without trees $\geq 3 \mathrm{~m}$ ) within the plots of GF $\left(\right.$ mean $\left.=39 \mathrm{~m}^{2}\right)$ and $\mathrm{UF}\left(\right.$ mean $\left.=24 \mathrm{~m}^{2}\right)$ differed significantly (Fig. 1). Most of the plots (95\%) in the GF had gaps between $25 \mathrm{~m}^{2}$ and $51 \mathrm{~m}^{2}$. The gaps in the UF were significantly smaller; their size ranged from $12 \mathrm{~m}^{2}$ to $37 \mathrm{~m}^{2}$. The mean percentage of gap area per plot area was $17 \%$ in the GF and $11 \%$ in the UF. One of the grazed plots, however, had a gap of $\sim 100 \mathrm{~m}^{2}$ (Fig. 1).

\section{AGE AND TREE-HEIGHT STRUCTURE}

The trees, meaning the species Norway spruce and European larch, were significantly younger in GF than in UF (Table 2). In the $\mathrm{GF}$, the percentage of trees belonging to the shortest-height class $\mathrm{H} 1$ (48\%) and the percentage of trees belonging to the medium-height class H2 (46\%) were slightly (but not significantly) higher than the percentages of trees of the same height classes in the UF (H1: 45\%; $\mathrm{H} 2$ : $41 \%$ ). By contrast, the percentage of trees taller than $25 \mathrm{~m}$ was significantly lower in the GF (6\%) than in the UF (14\%). The spruces and larches smaller than $3 \mathrm{~m}(\mathrm{H} 1)$ were both significantly younger and significantly taller in the GF than in the UF (Table 2). This indicates that the spruces in the GF grew faster than those in the UF. In $\mathrm{H} 2$, the larches in the GF were also significantly younger than in the UF, although the tree heights were not significantly different. Consequently, the larches in $\mathrm{H} 2$ also grew faster in GF than in UF. In the

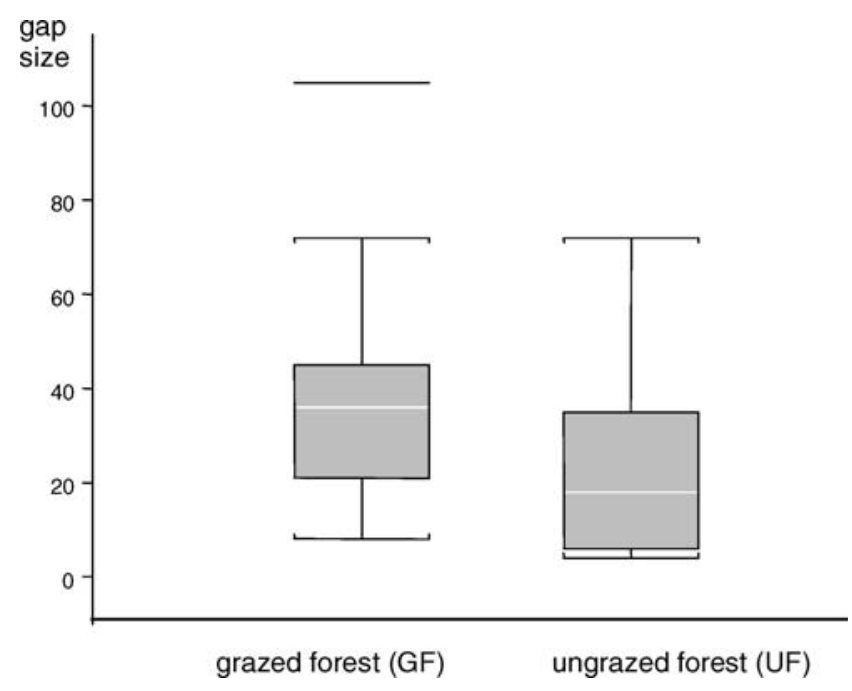

FIGURE 1. Average gap size (in square meters) in grazed (GF) and ungrazed forest (UF) plots; $n_{\mathrm{GF}}=15 ; n_{\mathrm{UF}}=15$. The white line in the box shows the mean value, the limits of the box are the $50 \%$ confidence interval, the ends of the black lines give the $95 \%$ interval, and the line in the upper left shows outlier.

spruces of $\mathrm{H} 2$, however, there was no significant difference between tree age in GF and UF. By contrast, the trees of $\mathrm{H} 3$ were significantly older in GF than in UF, but the tree heights did not differ significantly.

In total the age range in the plots of the GF was slightly wider than in the UF plots, which indicates that the forest stands in the GF have a more diverse age structure than in the UF. In $\mathrm{H} 1$, the age range was the same in GF and UF. In H2, and especially in $\mathrm{H} 3$, the age range in the GF was wider by several years compared to the age range in the UF.

The major part of the plots randomly selected in the GF were multilayered open (MO, Fig. 2), whereas in the UF, the major part of the plots randomly selected were uniform dense (UD), according to the classification of Bebi et al. (2001). Multilayered dense (MD) was a quite frequent structure type in both groups (20\% in the GF and $27 \%$

\section{TABLE 2}

Mean and standard deviation (average of all species, Picea abies, Larix decidua) of the age (in years) of grazed and ungrazed forests.

\begin{tabular}{lcc}
\hline \hline & Grazed forest & Ungrazed forest \\
\hline $\begin{array}{l}\text { All trees } \\
\text { mean age }\end{array}$ & $62^{\mathrm{a}} \pm 65,64^{\mathrm{a}} \pm 67,50^{\mathrm{a}} \pm 51$ & $73^{\mathrm{b}} \pm 62,73^{\mathrm{b}} \pm 62$, \\
& & $96^{\mathrm{b}} \pm 79$ \\
Trees $<3 \mathrm{~m}$ tall $(\mathrm{H} 1)$ & & \\
mean age & $29^{\mathrm{a}} \pm 11,30^{\mathrm{a}} \pm 11,26^{\mathrm{a}} \pm 12$ & $33^{\mathrm{b}} \pm 13,33^{\mathrm{b}} \pm 12$, \\
& & $42^{\mathrm{b}} \pm 24$ \\
mean height $(\mathrm{m})$ & $1.32^{\mathrm{a}} \pm 0.74,1.28^{\mathrm{a}} \pm 0.73$, & $1.13^{\mathrm{b}} \pm 0.81$, \\
& $1.72 \pm 0.77$ & $1.14^{\mathrm{b}} \pm 0.82$, \\
& & $1.30 \pm 0.73$ \\
Trees 3-25 m tall (H2) & & \\
mean age & $78 \pm 69,84 \pm 73,48^{\mathrm{a}} \pm 38$ & $87 \pm 55,87 \pm 55$, \\
& & $94^{\mathrm{b}} \pm 54$ \\
Trees $>25 \mathrm{~m}$ tall (H3) & & \\
mean age & $199^{\mathrm{a}} \pm 59,198^{\mathrm{a}} \pm 61,209 \pm 35$ & $164^{\mathrm{b}} \pm 67,161^{\mathrm{b}} \pm 67$, \\
& & $218 \pm 40$ \\
\hline
\end{tabular}

A. C. MAYer AND V. STÖCKLI / 523 


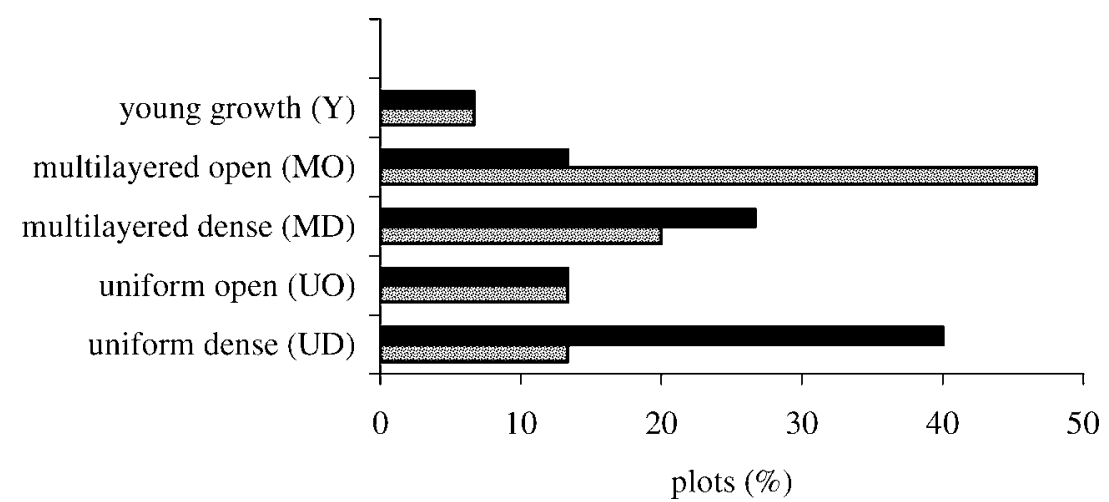

FIGURE 2. Frequency of forest-structure types of all grazed (dotted bars) and ungrazed plots (black bars) studied $(n=30)$, according to the classification of Bebi et al. (2001). in the UF). Both groups contained one plot in the young growth (Y) and two uniform open (UO) plots.

The age structure of $48 \%$ of the possible combinations of grazed and ungrazed plots was significantly different. Within the grazed plots, only $16 \%$ of the combination possibilities were significantly different. The age structure of the ungrazed plots differed in $23 \%$ of the possible combinations. This means that there were greater differences in age structure between the grazed and ungrazed plots than within the group of the grazed plots and the group of the ungrazed plots. Concerning the
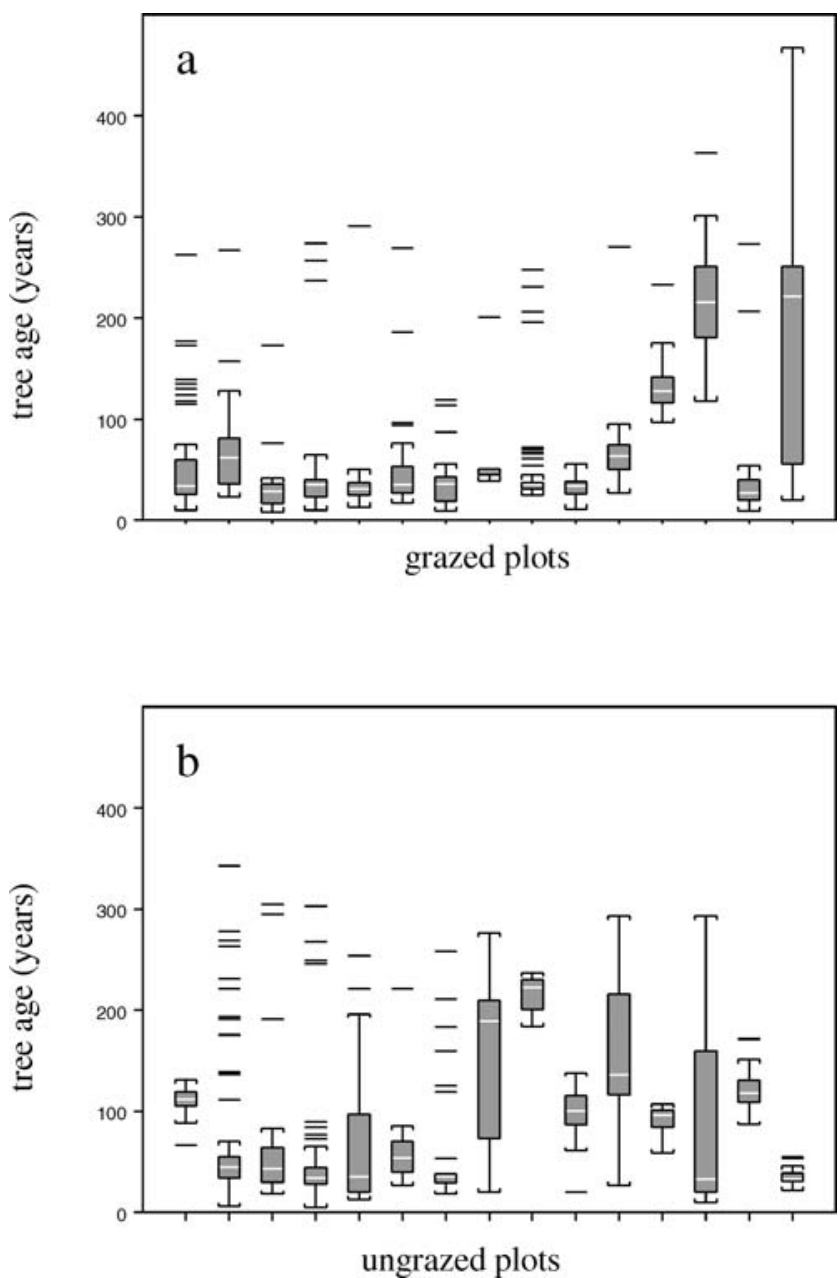

FIGURE 3. Age structure of all plots investigated. The white line in the box shows the mean value, the limits of the box are the $50 \%$ confidence interval, the ends of the black lines give the $95 \%$ confidence interval, and the dashes show outliers. A: Grazed plots. B: Ungrazed plots. height structure of the plots, this difference was even more obvious: between GF and UF, $52 \%$ of the possible combinations were different, whereas within the GF plots, only $18 \%$ were different and within the UF plots, $26 \%$ were different. Figure 3 shows the age range of the trees on the grazed and the ungrazed plots.

\section{Discussion}

The objective of the present study was to determine the long-term impact of cattle grazing on structure and avalanche-protection function of subalpine forests. In the Dischma Valley there are few significant differences in the age and height structure of grazed and ungrazed forests, but despite the long grazing history and contrary to the assumptions of forest deterioration due to grazing, the efficiency of grazed forests to prevent the release of avalanches is demonstrated.

Forest density and the size of forest openings define the immediate protection efficiency of a forest against avalanche release (Frey, 1977). In our study, forest stands used as wood pastures for many decades were found to be less dense than nearby ungrazed stands. This finding is in line with that of Bebi et al. (2001), who classified the forest structure based on aerial photographs. Saeki and Matsuoka (1969) found that a tree height of $150 \%$ of the snow-cover height is sufficient for avalanche protection; thus, the avalancheprotection threshold of a minimum tree height of $3 \mathrm{~m}$ is realistic for the study area, as the maximum snow depth is $\sim 2 \mathrm{~m}$ (Schönenberger and Frey, 1988). All the plots in the UF and $86 \%$ of the GF plots contained $>250$ trees $\geq 3 \mathrm{~m}$ tall per hectare, which is sufficient to provide avalanche protection (Meyer-Grass, 1987). However, target values concerning the efficiency of avalanche protection by forests are based on experience, theoretical calculations, and comparative studies, but there is little knowledge of the underlying quantitative physical basis of the avalanche-protection function of forests.

Age and height structure of a forest reflect the developmental history of the stand, determine the susceptibility of the stand structure to disturbance, and allow one to forecast potential changes in stand structure in the forthcoming decennials. Both age and height structure showed greater differences between grazed and ungrazed plots than within the group of the grazed plots and within the group of the ungrazed plots. The main forest-structure type in the grazed forest was multilayered open, whereas the main forest-structure type in the ungrazed forest was uniform dense. Subalpine forests usually tend to form stands of uniform height, although the age of the trees may differ considerably (Ott et al., 1997). The utilization of subalpine forests as wood pastures seems to counteract the natural tendency of the subalpine spruce-dominated forests to form uniform stands, thus favoring the development of a multilayered structure. A multilayered structure facilitates the regeneration and, consequently, the persistent avalanche-protection function of subalpine forests, as emphasized by Ott et al. (1997). In our study, there were fewer dominant trees taller 
than $25 \mathrm{~m}$ in the grazed forest, but these trees were significantly older than trees in the same height class in the ungrazed forest, reaching to $400 \mathrm{yr}$ in age. The reason for this phenomenon can most probably be found in past differences in logging activities. In grazed forests, a certain number of mature trees per area was usually left as shelter trees for grazing animals; in some regions it was forbidden by law to cut the shelter trees (Blumer, 1983). One reason for the lower density of grazed forest stands might be browsing and trampling by cattle. In previous experiments, very high cattle stocking rates on small ranges and for grazing durations exceeding the herbage supply were found to cause remarkable browsing damage (Mayer et al., 2005a). However, the results of field studies on wood-pasture ranges in the Dischma Valley traditionally used for grazing cattle (Mayer et al., 2002) suggest that the usual cattle stocking rates of $\sim 1-2$ livestock units per hectare are not sufficient to influence the forest structure remarkably. Also Liss (1988) found that cattle grazing does not severely impair the regeneration of subalpine forests if stocking rates are low. The main reason for the lower density of trees in the grazed forests might be the result of tree-cutting activities. On wood pastures, the farmers used to cut both mature trees and regenerating trees in order to improve the growth of the herbage plant species (Janett, 1943). Unintentionally, the reduction in competition because of cutting trees also improved the growth conditions for the remaining young trees, thus partly explaining the faster growth of the trees $<3 \mathrm{~m}$ tall on grazed compared to ungrazed plots. The young trees in the grazed and in the ungrazed forest might need $65 \mathrm{yr}$ and $90 \mathrm{yr}$, respectively, to reach the target height of $3 \mathrm{~m}$, on the basis of linearly extrapolating the average growth rate of the sample trees $<3 \mathrm{~m}$ tall. However, one has to consider the high age of $>400 \mathrm{yr}$ that the trees can reach, when dealing with such long regeneration periods.

The higher percentage of larches in grazed forests might be due to both the enhanced light supply due to cutting trees and the fact that the farmers usually spared the larches when cutting young trees (Janett, 1943). The enhanced light supply in the understory of grazed forests might also be due to the lower number of dominant trees $(>25 \mathrm{~m})$. The generally low percentage of rowans in the study area might be due to both wild and domestic ungulate browsing. Previous field studies and experiments showed that rowans were intensively browsed by cattle (Mayer et al., 2002). However, it has to be taken into account that wildliving animals, such as hare, red deer (Cervus elaphus), and roe deer (Capreolus capreolus), had access to all sample plots. These animals are known to use the shoots of young trees as a feed resource (Bergström and Guillet, 2002), as demonstrated by the fact that in Switzerland, $15 \%$ of the young trees were found to be damaged by wild-living animals (Brassel and Brändli, 1999). However, it has also to be taken into account that there are additional factors influencing the frequency of rowans, e.g., the fact that the seeds are distributed by birds. The distribution of stone pines is known to mainly depend on the activity of nutcrackers (Lauber and Wagner, 1996), whose rarity in the study area might explain the low percentage of stone pines there.

\section{Conclusions}

The wood-pasture management applied in our study area allowed evaluation of the combination of grazing, forest regeneration, and avalanche protection. The abundant natural regeneration-favored by the enhanced light regime - even allowed the felling of young trees by the farmers without endangering the future avalanche-protection function of the forest. The timber cannot be harvested cost-efficiently anymore owing to low timber prices; thus, there is little logging activity, as the increase of standing-timber volume by $2.5 \mathrm{~m}^{3} \mathrm{ha}^{-1} \mathrm{a}^{-1}$ in Switzerland demonstrates (Brassel and Brändli, 1999). Consequently, uniform stands are developing in big areas. Management of a forest as a wood pasture seems to enhance the readiness of the forest owners to conduct selective logging operations. Thus, forest grazing can encourage the development of heterogeneously structured forest stands, which can regenerate more easily while fulfilling an avalancheprotection function. Additionally, more open and heterogeneously structured forests have a higher plant species diversity (Gillet et al., 1999; West, 1993) and provide a habitat for rare wild-living animals, such as the capercaillie (Tetrao urogallus) (Marti and Rudmann, 1998). Furthermore, tourists prefer subalpine wood pastures compared to dense forests or open pastures (Ten Klooster, 2000). Thus, the utilization of wood pastures can be compatible with the avalanche-protection function of a mountain forest and in addition meets other demands, such as a landscape amenity and plant and animal species diversity.

\section{Acknowledgments}

We are grateful to Ursina Kasser and Flurina Burkhardt for their help in collecting and analyzing tree cores. We thank Peter Bebi for his assistance in the selection of the sample plots. And we especially thank Fritz Schweingruber for assistance during sample collection.

\section{References Cited}

Bebi, P., 1999: Erfassung von Strukturen im Gebirgswald als Beurteilungsgrundlage ausgewählter Waldwirkungen. Ph.D. thesis, Swiss Federal Institute of Technology (ETH), Zürich, 125 pp.

Bebi, P., Kienast, F., and Schonenberger, W., 2001: Assessing structures in mountain forests as a basis for investigating the forests' dynamics and protective function. Forest Ecology and Management, 145: 3-14.

Bergström, R., and Guillet, C., 2002: Summer browsing by large herbivores in short-rotation willow plantations. Biomass and Bioenergy, 23: 27-32.

Blumer, E., 1983: Die Betreuung der Wälder im Glarnerland. Glarus, Switzerland: Tschudi Druck und Verlag AG, 149 pp.

Bosshard, W. (ed.), 1986: Der Naturraum und dessen Nutzung im alpinen Tourismusgebiet von Davos. Birmensdorf, Switzerland: Reports of the Swiss Federal Institute for Forest, Snow and Landscape Research WSL, 289, 336 pp.

Brassel, P., and Brändli, U.-B. (eds.), 1999: Schweizerisches Landesforstinventar. Ergebnisse der Zweitaufnahme 1993-1995. Berne: Haupt, 442 pp.

Brugger, S., 2003: Vegetation und Lawinen. Diploma thesis, University of Zurich, Zürich, Switzerland, $65 \mathrm{pp}$.

Bundesamt für Umwelt, Wald und Landschaft BUWAL, 1999: Wie nachhaltig ist die Schweizer Forstpolitik? Zusammenfassung. Bern: Schriftenreihe Umwelt Nr. 313, 61 pp.

Domes, N., 1947: Untersuchungen über Waldweide. Die Waldweide und die Ermittlung des Waldweideertrages. Zentralblatt für die gesamte Forst- und Holzwirtschaft, 70: 39-51.

Domes, N., 1952: Untersuchungen über Waldweide. Entwurf einer provisorischen Waldweideertragstafel. Zentralblatt für die gesamte Forst- und Holzwirtschaft, 71: 341-354.

Duncan, R. P., 1989: An evaluation of errors in tree age estimates based on increment cores in kahikatea (Dacrydarpus dacrydioides). New Zealand Natural Sciences, 16: 31-37.

Fankhauser, F., 1870: Waldweide Haupthindernis zur Wiederverjüngung der Gebirgswaldungen. Massregeln, den Weidgang für die Waldungen möglichst unschädlich zu machen. Swiss Journal of Forestry, 85: 113.

Frey, W., 1977: Wechselseitige Beziehungen zwischen Schnee und Pflanze. Davos: Mitteilungen des Eidgenössischen Instituts für Schnee- und Lawinenforschung, 34, $223 \mathrm{pp}$.

Gillet, F., Murisier, B., Buttler, A., Gallandat, J.-D., and Gobat, J.-M., 1999: Influence of tree cover on the diversity of herbaceous communities in subalpine wooded pastures. Applied Vegetation Science, 2: 47-54.

Günter, T. F., 1984: Nutzungsgeschichte von Davos. Eine empirische Untersuchung über Nutzungsänderungen unter dem Einfluss des 
Tourismus seit 1900. Dissertation thesis, University of Zurich, Zürich, Switzerland, 169 pp.

Günter, T. F., 1986a: Nutzungsgeschichte. In Bosshard, W. (ed.), Der Naturraum und dessen Nutzung im alpinen Tourismusgebiet von Davos. Ergebnisse des Man and Biosphere-Projektes Davos. Birmensdorf, Switzerland: Reports of the Swiss Federal Institute for Forest, Snow and Landscape Research WSL, 289, 215-238.

Günter, T. F., 1986b: Das Testgebiet Davos. In Bosshard, W. (ed.), Der Naturraum und dessen Nutzung im alpinen Tourismusgebiet von Davos. Ergebnisse des Man and Biosphere-Projektes Davos. Birmensdorf, Switzerland: Reports of the Swiss Federal Institute for Forest, Snow and Landscape Research WSL, 289, 21-29.

Imbeck, H., 1983: Die Lawinenschutzwirkung des Waldes. Mitteilungen des Eidgenössischen Instituts für Schnee- und Lawinenforschung Davos, 43: 57-67.

In der Gand, H., 1978: Verteilung und Struktur der Schneedecke unter Waldbäumen und im Hochwald. In In der Gand, H., Kronfeller, G., Ott, E., and Salm, B. (eds.), International Seminar on Mountain Forests and Avalanches. IUFRO Working Party on Snow and Avalanches. Davos: Swiss Federal Institute for Snow and Avalanche Research, 98-119.

Janett, A., 1943: Über die Regelungen von Wald und Weide. Swiss Journal of Forestry, 94(4): 105-117.

Johnson, E. A., 1987: The relative importance of snow avalanche disturbance and thinning on canopy plant populations. Ecology, 68: 43-53.

Krause, M., and Peyer, K., 1986: Böden. In Bosshard, W. (ed.), Der Naturraum und dessen Nutzung im alpinen Tourismusgebiet von Davos. Ergebnisse des Man and Biosphere-Projektes Davos. Birmensdorf, Switzerland: Reports of the Swiss Federal Institute for Forest, Snow and Landscape Research WSL, 289, 87-106.

Laely, A., 1984: Der Wald in der Geschichte der Landschaft Davos. Davoser Heimatkunde: Beiträge zur Geschichte der Landschaft Davos. Davoser Revue, 1984(2): 62-126.

Lauber, K., and Wagner, G., 1996: Flora Helvetica. Bern: Paul Haupt, $1616 \mathrm{pp}$.

Liss, B.-M., 1988: Der Einfluss von Weidevieh und Wild auf die natürliche und künstliche Verjüngung im Bergmischwald der ostbayerischen Alpen. Forstwissenschaftliches Centralblatt, 107: 14-25.

Marti, C., and Rudmann, F., 1998: Das Auerhuhn-Ein Bewohner der Moor-Waldkomplexe, Handbuch Moorschutz in der Schweiz 1. Sempach, Switzerland: Vogelwarte Sempach, $18 \mathrm{pp}$.

MathSoft Inc., 1999: S-Plus 2000 user's guide. Seattle, Washington: Data Analysis Products Division, MathSoft, 557 pp.

Mayer, A. C., 2003: Range management on wood pastures of an Alpine valley. Austrian Journal of Forest Science, 120(1): 19-28.

Mayer, A. C., Stöckli, V., Konold, W., Estermann, B. L., and Kreuzer, M., 2002: Effects of grazing cattle on subalpine forests. In Bottarin, R., and Tappeiner, U. (eds.), Interdisciplinary Mountain Research. Berlin: Blackwell Verlag GmbH, 208-218.
Mayer, A. C., Estermann, B. L., Stöckli, V., and Kreuzer, M., 2005: Experimental determination of the effects of cattle stocking density and grazing period on forest regeneration on a subalpine wood pasture. Animal Research (in press).

Mayer, A. C., Stöckli, V., Konold, W., and Kreuzer, M., 2005: Influence of cattle stocking rate on browsing of Norway spruce in subalpine wood pastures. Agroforestry Systems (in press).

McArthur, A. J., 1991: Forestry and shelter for livestock. Forest Ecology and Management, 45: 93-107.

Meyer-Grass, M., 1987: Waldlawinen: Gefährdete Bestände, Massnahmen, Pflege des Gebirgswaldes. In Bischoff, N. (ed.), Pflege des Gebirgswaldes: Leitfaden für die Begründung und forstliche Nutzung von Gebirgswäldern. Berne, Switzerland: EDMZ, 379 pp.

Okland, T., Rydgren, K., Okland, R. H., Storaunet, K. O., and Rolstad, J., 2003: Variation in environmental conditions, understorey species number, abundance and composition among natural and managed Picea abies forest stands. Forest Ecology and Management, 177: $17-37$.

Ott, E., 1996: Leitbilder zur Schutzwirkung des Waldes vor Lawinenbildung. Forstwissenschaftliches Centralblatt, 115: 223-230.

Ott, E., Frehner, M., Frey, H.-U., and Lüscher, P., 1997: Gebirgsnadelwälder. Ein praxisorientierter Leitfaden für eine standortgerechte Waldbehandlung. Bern: Verlag Paul Haupt, 288 pp.

Pollanschütz, J., 1995: Bewertung von Verbiss- und Fegeschäden. Wien, Austria: Mitteilungen der Forstlichen Bundesversuchsanstalt, 169: 99.

Saeki, M., and Matsuoka, H., 1969: Snow-buried young forest trees growing on steep slopes. Seppyo: Journal of the Japanese Society of Snow and Ice, 31: 19-23.

Salm, B., 1978: Snow forces on forest plants. In In der Gand, H., Kronfeller, G., Ott, E., and Salm, B. (eds.), International Seminar on Mountain Forests and Avalanches. IUFRO Working Party on Snow and Avalanches. Davos, Switzerland: Swiss Federal Institute for Snow and Avalanche Research, 156-181.

Salm, B., Zarn, B., and Bigger, V., 1987: Vorlesung Schnee, Lawinen und Lawinenschutz. Zürich: ETH, 270 pp.

Schönenberger, W., and Frey, W., 1988: Untersuchungen zur Ökologie und Technik der Hochlagenaufforstung: Forschungsergebnisse aus dem Lawinenanrissgebiet Stillberg. Swiss Journal of Forestry, 139: 735-819.

Stokes, M. A., and Smiley, T. L., 1968: An introduction to tree ring dating. Chicago: University of Chicago Press, 73 pp.

Ten Klooster, L., 2000: Waldweide als Teil der alpinen Kulturlandschaft. Diplomarbeit thesis Universität für Bodenkultur Wien, Wien/ Wageningen, $126 \mathrm{pp}$.

West, N. E., 1993: Biodiversity of rangelands. Journal of Range Management, 46: 2-13.

Wildi, O., and Ewald, K. (eds.), 1987: Der Naturraum und dessen Nutzung im alpinen Tourismusgebiet von Davos. Ergebnisse des MaB-Projektes Davos. Birmensdorf, Switzerland: Berichte der Eidgenössischen Anstalt für das Forstliche Versuchswesen, 336 pp.

Ms submitted December 2003 